\title{
A Blast Into Dark Immortality
}

\section{Mumia Abu-Jamal}

To kill someone for committing murder is a punishment incomparably worse than the crime itself. Murder by legal sentence is immeasurably more terrible than murder by brigands.

Fyodor Dostoyevski

The Idiot (1868)

Late summer and fall 1990 will be marked in the American mind by more than the saber rattling that preceded the blitzkrieg in the Arabian gulf. Many Americans will also recall the gripping terror that covered the southern city of Gainesville, Florida, a community of more than 80,000 souls, where a spree of midnight murders splashed crimson over the nation's psyche.

According to published reports, a person (or persons) unknown, assaulted, murdered and mutilated four young people with a degree of precision and organization that seemed to negate the presence of compassion. Reports told of a perverse penchant for posing the victims' bodies as lifeless mannequins, apparently to create maximum shock effect on whoever found them. Wire service reports revealed every lurid detail, and before long the name Gainesville evoked a label that is utterly American in origin: the 'serial killer'.

More remarkable, however, was the invocation of a single name by University of Florida students interviewed by the media. That name, one tinged with a dark, fascinating power, was Ted Bundy! Out of the cryptic collective unconscious sprang the visage and persona of a man surely put to death in Florida's steaming electric chair, but apparently also as alive as human memory itself.

This instant leap of Bundy's image to Floridian and national consciousness speaks volumes on the inherent failure of the American 
death penalty. Had he been left to serve a term of years in prison like thousands of his criminal contemporaries, America's dark fascination with Bundy would have paled. By searing his flesh, the state has made him bigger than life! Bigger than death! And in doing so it may have encouraged others to follow his lead.

There is something very American about violence. "Violence," quoth the former Black militant H. Rap Brown, "is as American as apple pie." Now Muslim Imam Jamil Abdullah, his words stirred Black passions and stoked white anger, but few would dispute the fact that extraordinary levels of retail social violence (e.g. murder) and wholesale official violence (e.g. the death penalty) dominate the American landscape and flavour its post-Columbian history. A wealth of statistical data suggests America is the unrivalled leader in murders, rapes and other crimes of violence against persons. Today, when millions strain against the boundaries of the Earth's frontiers, Americans seem to redirect their energies inward, producing more than 20,000 murders annually, more in number and per capita than any other place on this fragile planet (U.S. Department of Justice, 1989: 49). 1

The phenomenon of the 'serial killer' (with the notable exception of the British legend 'Jack the Ripper') seems peculiarly American and male. Until quite recently, the typical 'serial killer' was best described as an intelligent, white male apparently acting out fantasies of dominance against younger and physically weaker females, culminating in mutilating violence featuring the forbidden frisson of the psycho-sexual. 2 Ted Bundy, a former law school student described as 'brilliant' by those who knew him, fit this description perfectly.

Many countries with economic and political systems quite similar to the United States are moving away from the use of the death penalty. Nonetheless, America increasingly stands apart from these 'civilized' nations and alongside countries such as Iraq, South Africa, China, and the U.S.S.R. which have retained and aggressively employ capital punishment. Meanwhile, the use of the death sentence in the U.S. has had no measurable effect on national, or regional, murder rates ("Murder in the City", 
August 6, 1990: 3A). These elements of American violence high murder rates, the 'serial killer' and the death sentence converged in Gainesville in the invocation of Ted Bundy's name. What does this mean?

Perhaps the violence is an expression of American myths about this country's origins: a portrayal of the great, white, male civilizer, tamer and lawgiver who largely eradicated native peoples. Or is it a manifestation of the genetic material which forms the background of thousands of Americans whose ancestors were transported to Britain's colonies to relieve overcrowding in English jails. America, the world's policeman, was once perceived as world criminal. The English poet Samuel Johnson, commenting on this country during the revolutionary era, noted:

They [Americans] are a race of convicts, and ought to be thankful for anything we allow them, short of hanging (Johnson, May 27, 1775).

To be sure, much of Johnson's antipathy can be traced to his loyalty to the British Crown and his anger at the upstarts who murmured rebellion, but there is a grain of truth in the claim that convicts exiled from England were sent to America for punishment. Indeed, what is now the sovereign state of Georgia was initially a British penal colony (Ehle, 1988: 255). However, if America's contemporary social violence is 'inbred' how does one explain the differences between this country and Australia - a land settled by massive immigration of convict populations followed by the eradication of its aboriginal population (Hughes, 1986)? The violent past is similar but Australia shares few of America's more violent characteristics. For example, Australia has neither the death penalty, a murder rate which approximates America's, nor serial killers.

Is it race? Although race of victim and perpetrator are demonstrably predictive factors in determining whether or not a death sentence is returned, it has not been a significant factor in the incidence of 'serial killings' 3 As previously noted, the overwhelming majority of 'serial killers' are white. Genetics and race will not do. We must look further. 
For a relatively short period of Bundy's life, America's ambivalent fascination with this man and his crime put his grinning visage in every major periodical and on every television tube. Who can remember the name of his trial judge, his appellate judge, his prosecutor, or even his victims? They pale beside the spectacle of Bundy, a celluloid spectre, a Mephistophelian memory, a symbol of silent infamy that survives the crypt. The state murder of Ted Bundy certainly ended his corporeal existence but hardly his spirit. In a perverse sense, Bundy lives. And thanks to his loud legion of detractors, the beer-swilling mob that cheered while he charred, and a flurry of Florida politicians scrambling for the coveted 'Bubba' vote, Bundy's state execution made headlines and careers. During the 1990 gubernatorial election, the Republican incumbent featured a cardboard cutout of Bundy in thirty-second television spots to show how he was 'tough on crime'("Murder in the City", August 6, 1990: 3A). 4

Since Florida boasts the nation's sixth highest murder rate, the street impact of the death penalty in general, and Bundy's execution in particular, should best be termed dubious. In fact, despite official denials, there may lurk in America's shadow a dark force, an almost palpable personality bent on emulating (or worse, outdoing!) Bundy. Is this yet unknown person being drawn like a gnat to a fatal, flickering flame: that odd American enterprise of instant celebrity, the addiction to be 'somebody', anybody but a nobody? In the monstrous entity of modernity that America has now become, many long to burst the bonds of their anonymity. If premeditated murder is the last act of social alienation, then 'serial killing' is its arch, elevated expression. To the anonymous, the alienated, the invisible, violence acts as a doorway to some measure of (albeit twisted) fulfillment, identity, visibility.

If this is the motive force, there is a sad irony in it. Whoever this poor soul is, in that creature called the public mind s/he will only be a 'copycat killer', Ted Bundy's dark acolyte, a pale horrid reflection of Bundy's greater genius, unless, of course, when s/he is found Florida's quick-thinking politicians elect to burn her/him in 'Big Bertha's Livid Griddle'. Then, perhaps we will hear of 
Journal of Prisoners on Prisons, Vol. 3, No. 1/2, Spring, 1991.

another who was too afraid to live in quiet desperation and decided to outdo Bundy: to earn a space in the electric sun, a moment on the evening news.

That'll show 'em!

Won't it?

\section{ENDNOTES.}

1. For 1988, 20,675 murders/non-negligent manslaughters are listed in U.S. Department of Justice statistics (U.S. Department of Justice, 1989: 49).

2. The author notes a recent case, also from Florida, which turns this generalization on its head. The accused is charged with robbing, murdering and mutilating males. Moreover, the accused is female.

3. See McCleskey v. Kemp, 481 U.S. 279, at 321 (Brennan, J., dissenting) (1987). Retired U.S. Supreme Court Justice Brennan's dissent noted that the proffered Baldus study showed defendants charged with killing whites are 4.3 times more likely to be sentenced to die as defendants charged with killing Blacks; six of every 11 defendants convicted of killing a white would not have received a death sentence had their victims been Black.

4. Interestingly, the resurrection of Bundy merited the incumbent little, for he was trounced by his populist opponent who won handily despite ignoring the issue of capital punishment (See "Murder in the City" August 6, 1990: 3A).

\section{REFERENCES}

Ehle, J. (1988) Trail of Tears: The Rise and Fall of the Cherokee Nation. New York: Doubleday.

Hughes, R. (1986) The Fatal Shore. New York: Vintage Books.

Johnson, S. (May 27, 1775) Letters to Earl of Chesterfield.

"Murder in the City" (August 6, 1990), USA Today, 3A.

U.S. Department of Justice, Federal Bureau of Investigation (1989) Crime in the United States, 1988. Washington D.C.: Department of Justice. 
